\title{
Nagy, Zsolt. 2017. Great Expectations and Interwar Realities: Hungarian Cultural Diplomacy, 1918-1941. Budapest: Central University Press. 341 pages
}

\author{
Reviewed by Mártha Pereszlényi-Pintér', John Carroll University, Cleveland, Ohio
}

Zsolt Nagy is a historian of Modern Europe with specific focus on East and East-Central Europe at the University of St. Thomas, Saint Paul, Minnesota. Nagy's monograph (begun as his Ph.D. dissertation thesis at the University of North Carolina at Chapel Hill) consists of an introduction, five chapters, and a conclusion. Various definitions of "cultural diplomacy" include "self-advertisement," "image cultivation," "nation branding," and "national reputation management." The Introduction defines the intent of this monograph: to explore this concept in Hungary as a less direct form of propaganda since post-WWI up to and including WWII. The goal of this propaganda was to provide a public-relations campaign and thus project a positive image of Hungary both inside the country and abroad. The covert - and oftentimes overt agenda of the time included the goal of revisionism, meaning revising the Trianon Treaty, which the majority of the population and its leaders agreed should be the primary goal of foreign policy.

In Chapter 1, "Mobilizing the Nation: From War Propaganda to Peacetime Cultural Diplomacy and Beyond," Nagy contextualizes the construction of interwar cultural diplomacy in Hungary and elsewhere, starting with the war years (1914-18) and followed by Mihály Károlyi’s government-established Országos Propaganda Bizottság ['National Propaganda Committee'] that devised the Slogan "Nem, nem soha!" ['No, No, Never!'], the rallying cry of Hungarian irredentist organizations for years to come. Following the 1920 Treaty of Trianon, the country's leadership believed that the "resurrection" of the country depended on its image abroad, which meant that armed conflict and saber rattling were out of the question. In the 1920s, the KÜMKülügyminisztérium [Hungarian 'Foreign Ministry'] established a political intelligence division. This was the first step in carrying out Hungary's cultural diplomacy, whereby the government was to distance itself from emotionally charged, grievance-driven propaganda. Practitioners of cultural diplomacy targeted their propaganda toward these entities: 1) the Great Power countries, 2) the United States, and 3) the League of Nations. A downward spiral, however, began with the 1938 Anschluss and Hungary's drawing closer to the Rome-Berlin Axis. Territorial reacquisitions via the Vienna Awards came at a steep price: political and economic concessions to Hitler and the Nazis.

${ }^{1}$ mpereszlenyi@jcu.edu

(cc) BY

ULLS D-Serke
New articles in this journal are licensed under a Creative Commons Attribution 4.0 International License.

This journal is published by the University Library System of the University of Pittsburgh as part of its D-Scribe Digital Publishing Program and is cosponsored by the University of Pittsburgh Press 
In Chapter 2, "Defining the Nation," Nagy investigates the ways in which competing visions of "Hungarianness" played a role in the construction of national identity. He also addresses the concept of "Europeanness," as the Hungarian elite strove to build a national identity that would enable the country to join the European community of nations. At the background of this ambition stood nineteenth-century European romanticism that had depicted Hungary as a land of passionate Hussars: generally sympathetic albeit anachronistic, chivalrous, gentlemanly folk who found pleasure in fighting, merrymaking and gypsy music. All these attributes were reminiscent of their wild, Oriental ancestors, which rendered Hungarians incapable of coping with modern, urban lifestyles. With such portrayal Hungary could not expect to be considered a "natural" part of enlightened Europe.

Nagy offers an overview of nemzetkarakterológia meaning the self-portrayal of the Hungarian nation's characteristics. The best-known and most often cited example of this selfportrayal is Sándor Eckhardt's contribution to Gyula Szekfü's 1939 essay collection entitled Mi a Magyar? ['What is Hungarian?'] (Budapest: Atheneum, 1939, 87-90). In Eckhardt's reading, the negative reputation of Hungary originated with the tenth-century Western-European campaigns of the Hungarian tribes. The image of a barbaric and bloodthirsty wild race was resurrected in the 1823 French fables of Charles Athanase Walckenaer, who connected the old French word Hongre ['Hungarian'] with the word "ogre" ['monster']. Eckhardt also mentions French historian Charles Seignobos, who in 1937 claimed that the Hongrois left no trace because they had become ogres, meaning supernatural beings that eat children. Although Seignobos and others praised the fighting spirit of Hungarians during the Ottoman attacks when the "Shield of Christianity" and "the Bastion of the West" earned Hungarians positive images, Hungary was still represented as an uneducated, uncultured, and uncivilized state.

Nagy presents his own four different versions of Hungarianness: 1) radical liberals, meaning later urbánusok from among Budapest's young and bourgeois circles; 2) fajvédök ['race defenders'] who had served in the young officers' corps of the k.u.k. [German: 'kaiserlich und königlich'] army units, and who opposed liberals and foreign influences, meaning Jews as well as German notions. To them, the Hungarian peasantry remained the guardian of the country's Oriental past and as such safeguarded the future; 3) népiek ['folksy' or 'popular']) dreaming of a new Hungary based on peasant traditions and peasant culture; and 4) conservative national liberals who promoted a European, i.e., Western orientation.

Nagy's Chapter 3 focuses on "Educating International Public Opinion: Cultural Institutions and Scholarly Publications." Hungarians of the time argued that the outcome of Trianon might have been different had Western public opinion not perceived Hungary as a fairytale land of shepherds, gypsies, and oligarchs. To address these issues, Hungarian propagandists launched a cultural diplomatic campaign and designed a new tudománypolitika ['science policy'] focusing on enlightening international intellectual elite circles. The VKM Vallás és Közoktatásügyi Minisztérium ['Ministry of Religion and Public Education'] and the KÜM - Külügyminisztérium ['Foreign Ministry'] together reorganized the country's cultural production. The VKM received financial support for a program that included establishing the Collegium Hungaricum system abroad with a dual purpose: to assist Hungarian students studying abroad and to function as representative institutions of Hungarian culture, including housing exhibitions and libraries, such as a Hungarian Reference Library in New York City. In the United States support was available for radio stations playing Hungarian music, lectures about Hungarian achievements, and courses in Hungarian language at various universities. While the 
goal of establishing and maintaining cultural presence in other countries was parallel with convincing Western countries that the Vienna Awards were unjust, it faced serious competition from its neighbor states such as Romania and Czechoslovakia that claimed the opposite. Scholarly publications came into play as well. R.W. Seton-Watson's journal The New Europe, and later the Revue de Transylvanie, were decidedly anti-Hungarian. Hungarian leadership called for scholarly yet accessible journals to counter, which resulted in founding Hungarian foreignlanguage journals such as the Nouvelle Revue de Hongrie and the Hungarian Quarterly.

In Chapter 4, "Showcasing the Nation: The Role of Tourism," Nagy describes how Hungary was to become a travel destination for foreigners, with the desired outcome of satisfied tourists who, upon returning to their home countries, could turn into goodwill ambassadors. PreWWI tourism had focused on Hungary either as of no particular interest, or as a "land of beautiful women, fine horses, good wine, and gypsy music," both of which helped create a puszta ['wilderness' or 'wasteland'] romanticism about the country. Indeed, post-WWI photos and descriptions in foreign language guidebooks still depicted Hungary as the land of fortune-telling gypsies and medieval conditions. But by the 1930s, Hungary had travel bureaus in numerous countries, with their prime target being the U.S., which had never ratified the postwar treaties, not to mention that American tourists had the most money. Nevertheless, tensions and rifts existed between two cultural currents. The népi focused on traditionalism and insisted that the essence of Hungarianness was rooted in the countryside, which was not entirely free of antiSemitic notions (although Nagy asserts that it would be a mistake to equate it with antiSemitism). By contrast, the urbánus was popular among Budapest's (often Jewish) intellectual circles exactly because it was modern, progressive, cosmopolitan and thus on par with Paris or Berlin. Nagy includes eight color plates of Hungária Magazin cover art, one of which depicts a vibrant nightlife with a sophisticated dance hall framed by a window overlooking the lights of the Danube. He mentions the EMKA bar, where patrons could enjoy both gypsy music and jazz, while other nightclubs such as the Arizona offered cabaret and revue performances on a revolving stage, including scantily clad görls (interwar slang for "girls"). Yet another component was Lake Balaton, whose image sought to combine progress and modernity with the natural beauty of the countryside. (A Hungária Magazin cover art image with a strikingly sophisticated young woman graces the cover of Nagy's monograph.)

In Chapter 5, "Becoming Audible and Visible: Radio Broadcasting and Cinematic Production in the Service of Cultural Diplomacy," Nagy describes the development of modern media and its impact on Hungarian cultural diplomacy. Radio broadcasting had three goals: 1) to provide entertainment and make money; 2 ) to propagate Hungarian culture and achievements abroad; 3) to serve as a conduit to Hungarians living outside the postwar borders. Debates about the Hungarianness of radio musical programming, with special emphasis on the role of foreign composers and genres including the musical heritage of Gypsies and Jews, were rampant. Miklós Kozma, head of the MTI - Magyar Távirati Iroda ['Hungarian Telegraph Bureau'], openly acknowledged radio's role as being one of cultural diplomacy's "sharpest weapons." The development of this "sharpest weapon" did not go unnoticed in the international community, which recognized that radio could become a potent political weapon: short wave broadcasts to the ethnic Hungarian of the post-Trianon territories as well as to those living in the U.S.A. Domestic dilemma transpired: rightists and vocal irredentist argued that only Hungarian language and music should be broadcast. Was the Hungarian gypsy-style magyar nóta ['Hungarian tune'] to be the representative of Hungarian music, or was it the "authentic" sound of 
népdal ['folksongs'] as espoused by Bartók and Kodály? In addition, radio programming came under pressure to ban any music or other work that originated or was performed by Jews. For example, Sándor Petőfi's János Vitéz ['John the Hero'] was a hugely popular musical composed by Pongrác Kacsóh, but since the lyricist Jenő Heltai was Jewish, it could not be performed.

The second part of Chapter 5 examines cinema. Nagy concentrates on Kulturfilme and newsreels which had three target audiences: Hungarians at home, Hungarians abroad, and foreigners. Their goals were to present Hungary's traditions and history along with its image as a modern, progressive, and European country. Here, propaganda supporting revisionism continued, depicting Hungary as the bastion of the ungrateful West. The advent of the "talkies" brought new concerns, especially for feature films. Stories were little different from their Hollywood counterparts, painting a picture of bourgeois life where people danced the foxtrot and enjoyed modern life. Filmmaker Paul Fejös argued that Hungarian film could not compete with Hollywood, and therefore should provide "exotica" that might be giccs ['kitsch'] but which would open the American market to Hungarian films. In the concluding chapter, Nagy reasserts the main leitmotif of interwar Hungarian foreign policy: revisionism. But interwar cultural diplomacy failed for two main reasons: first, the elite's mistaken belief in the inherent and obvious greatness of Hungary and the justice of its cause, and second, the mistaken assumption that Hungarian problems carried significant weight in the interests of the Great Powers.

In conclusion, in his Great Expectations and Interwar Realities, Zsolt Nagy offers a new interpretation of interwar diplomatic history and the construction of national identity in EastCentral Europe by examining the period not as a prelude to WWII but as a postlude to WWI. This monograph is not light reading. The amount of documented information offered in it is staggering. It appears to be intended for an academic audience or for the reader with a profound interest in the interwar historical period. Nagy is to be commended for his riveting contribution to the growing body of literature on cultural diplomacy. 